\title{
The organizational ecological resource framework of sustainability reporting: implications for corporate social reporting (CSR)
}

\author{
Seleshi Sisaye
}

Palumbo-Donahue School of Business, Duquesne University, Pittsburgh, Pennsylvania, USA

\begin{abstract}
Purpose - The purpose of this research is to provide an integrated approach of organizational ecology, population ecology and selection mechanisms within the context of the resource-based view of the firm, evolutionary economics (EC) and transaction cost economics (TCE). It applies this framework to examine the interrelationships between corporate social reporting (CSR) and global reporting initiative.

Design/methodology/approach - The methodology for this paper is library-based archival research. It is qualitative and analytically descriptive of prior academic research and published literature on the subject.

Findings - CSR has the potential to provide functional credence to corporate social and environmental activities by legitimizing institutionalized corporate norms and behavior.

Originality/value - Accounting scholars have recognized the need for an integrated approach in the social sciences to examine the multifaceted aspects of sustainability development and accounting. This research highlights that sustainability is related to ecosystems, environments, natural resources, demography, population, culture, political systems and history.

Keywords Sustainability accounting and reporting, Organizational ecology, Corporate social reporting (CSR), Population ecology and evolution, Selection and adaptation, Stakeholders management and transaction costs Paper type Research paper
\end{abstract}

The organizational ecology approach has its theoretical foundation in the structural functional (SF) assumptions of organizational change. Consequently, the process of natural selection within a population of organizations has a functional role in influencing social behavior and interactions among groups, physical and psychological adaptations, and the social structure of organizations (Carroll, 1984; Hannan, 1977).

The organizational ecological approach is based on the premise that organizational systems influence the formation and operations of class and economic structures to regulate social and political order as well as environmental resources management. The approach views sustainability and CSR as involving organizational adaptation and selection

(C) Seleshi Sisaye. Published in Journal of Business and Socio-economic Development. Published by Emerald Publishing Limited. This article is published under the Creative Commons Attribution (CC BY 4.0) licence. Anyone may reproduce, distribute, translate and create derivative works of this article (for both commercial and non-commercial purposes), subject to full attribution to the original publication and authors. The full terms of this licence may be seen at http://creativecommons.org/licences/by/4.0/ legalcode

The author greatly acknowledges the substantial comments of the two anonymous reviewers and the Editor off the journal. Their suggestions have improved the scope of the paper. The author assumes responsibility for the final product.

The ecology of corporate social reporting 
JBSED

2,2

mechanisms that are governed by transaction cost economics (TCE), evolutionary economics and stakeholders governance structures.

\section{Research framework}

Barnett and Carroll (1995) discussed two approaches to organizational change - the adaptation and the selection mechanisms. These approaches are applied to study sustainability development and CSR. The adaptation process assumes that there are a series of sequential stages (life cycles) of evolution in organizational development and societal changes over time. According to Carroll (1984), the evolutionary process provides the capability for "organizations (to) change structurally over time and that the form of change is shaped by structural pressures and constraints" (p. 73). Organizations are "highly adaptive and structural changes occur in response to internal and external simulations" (p. 73). Externally, "environmental conditions constrain the organization and shape organizational structure; however, external constraints such as size and technology also affect its structure" (p. 73). In this context, organizational survival depends upon the organization's ability to adapt and sustain resources as it interacts with the external environment. The extent to which organizations can adapt and change their strategies primarily depends on external environmental factors and the size of the population.

The selection mechanism, on the other hand, focuses on organizational population (Hannan, 1977). Population ecology "focuses on the demography of organizational populations (births and deaths of organizations)" (Baker et al., 1998, p. 173). The approach describes the "relationship between population density and rates of founding, failure and growth" (Barron, 1999, p. 424). Organizations go through the selection process of organizational maturity, survival and death. The selection approach is inherently inclusive of organizational adaptation as it assumes that there is a selection process in organizational strategies for survival and adaptation to the external environment.

Ecologically, sustainability involves transactions between adaptation and selection as the process requires organizations to adapt their structures and select strategies and policies to meet the demands of the external environmental constituencies that comprise the various contending stakeholders. Sustainability can reduce the prospects of organizational discontinuance and death. Accounting systems as part of organization structures undergo adaptive incremental changes. Accounting innovations feature both selective and adaptive features since they constitute innovative approaches and new techniques to account and report sustainability performances. It is within this adaptation/selection framework that this research addresses sustainability and CSR.

The purpose of this research is three-fold: First, to provide an integrated approach of organizational ecology, population ecology and selection mechanisms within the context of the resource-based view of the firm, EC and the TCE; second, to apply the framework to examine the interrelationships between sustainability development and CSR; third, and although CSR is voluntary, it has been embedded in global reporting initiative (GRI) as more business organizations use CSR as part of GRI or as a supplemental standalone report. The CSR approach to GRI can provide an integrated approach for sustainability reporting of financial, environmental and social performances of organizations.

The paper is organized into four sections. The first section discusses the underlying framework of organizational ecology, resource-based view of the firm, EC and TCE as it relates to sustainability development and reporting. The second part links these theories to CSR foundations in sustainability reporting. The third section traces how CSR has provided the underlying framework for GRI. The fourth section is the conclusion, which presents the theoretical limitations of CSR and suggests future areas of research. 
Section one: the general framework of organizational ecology

Organizational ecology is an evolutionary theory that describes structural changes in organizations as being dependent on the life cycle theory. The evolutionary process has immediate effects that are significant at early stages of founding and decline over time at later growth stages. Accordingly, organizational populations go through a series of sequential stages (life cycles) of evolution in organizational development and societal changes over time.

The ecological approach to organizational adaptation utilizes the selection process, whereby organizational resources are allocated in change programs, where the original domain existed, and competencies are well developed. The change process can contribute to organizational evolution of survival or decline depending on the number of organizations within a given population. The implications to sustainability are evident in this theory. That is, unsustainable organizational practices and strategies may be selected by ecological pressures, and that such organizations may face a decline in population density, or mortality. Sustainable practices may allow for greater firm density and a rise in survival rates for organizational populations (Salimath and Jones, 2011).

Selection shapes the magnitudes, frequency and direction of organizational adaptation to environmental dynamism (Stieglitz et al., 2016). Adaptation is intentional decision-making undertaken by organizational members to bring observable actions of change, performance and survival by minimizing the barrier between an organization and its economic and institutional environments (Sarta et al., 2021). Organizational adaptation involves the interrelationship between selection and variation, which offers a trade-off, i.e. transactions that enable organizational adaptation and learning (Levinthal and Marino, 2015). Organizations can use sustainability as a trade-off for compliance and learning by avoiding external transaction costs.

Organizational evolution and coevolution (Astley, 1985) are based on the Darwinian principle that selection and adaptation involve organizational routines and strategic choices as they undergo transformational changes (Hodgson, 2013). While organizational routines are sources of inertia which may slow organizational change, reduced level of inertia changes may act as a source of variation for organizations to keep surviving, to exhibit improved performance over time and adapt gradually to both endogenous and exogenous environmental factors (Yi et al., 2016). Sustainability accounting and reporting practices are low levels of inertia changes that organizations undertake to account for their social and environmental performances in CSR. They are part of the organization structures that undergo low-paced incremental innovations to respond to environmental changes. The selection process as an organizational domain dictates resource utilization and the incurring of transaction costs as a trade-off for sustainability and CSR.

\section{The resource-based view of the firm}

The resource-based view of the firm has its theoretical and practical foundations in the ecology of organizations literature. In general, organizational ecology has addressed the relationship between organizational resource availability, environmental conditions and strategic management policies to address these issues. The resource-based approach suggests that organizations seek to develop/maintain a competitive advantage over the available resources to meet their demands and opportunities by aligning their strategic plans with the environment. In the process, they develop a strategic fit to align organizational functional areas of management to achieve sustainable development objectives (Munck and Borim-de-Souza, 2012, pp. 404-405). Sustainability goals are thus dependent upon the organization's relationship to internal and external natural and environmental resources.

The resource-based view assumes that firms have resources - material, financial and human - and capabilities (skills) to have competitive advantage over others. Firms' unique
The ecology of corporate social reporting 
JBSED

2,2

102

competencies arise when they have an advantage over others in terms of "resources that are rare, non-substitutable, difficult to imitate, and valuable to customers" that are acquired due to "physical assets, employee skills, and organizational processes" (Buysse and Verbeke, 2003, p. 454). Firms' ability to manage these unique, nonsubstitutable and unimitative resources and capabilities (skills) provide competitive advantage that shape corporate sustainable business performances (Barney, 2001; Hart, 1995; Porter, 1985; Rumelt, 1974).

Bansal (2005) identified "three resource-based variables": "international experience," "capital management capabilities" and "organizational slack" (ample resources) as providing competitive sustainable development strategies (pp. 200-201). The availability of resources is dependent on the level of heterogeneity in a firm's ecological resources: physical, natural, economic and financial. If firms possess resource distinctiveness, capability and slack, Bansal (2005) suggested that they can become instrumental in shaping their early stages as well as sustaining long-term corporate sustainable environmental programs. They then have the resources to withstand externalities costs due to liability costs, legal fees or clean-up costs that are necessary to support improved organizational performance (Barney, 2001; Rumelt, 1974; Porter, 1985). Organizations undertake plans to innovate only when the environmental change(s) create constant threats to the organization's survival and/or growth strategies.

The political environment acts to enable access and control of valuable resources to shape how organizations utilize their competencies for managing the environment. Rudel et al. (2011) noted that "the political economy of the environment refers to how people control and, periodically, struggle for control over the institutions and organizations that produce and regulate the flows of materials that sustain people (corporations and the state)" (p. 222). CSR is an organizational political environmental self-regulated enterprise. Carroll's (1991) four dimensions of CSR - economic, legal, ethical and philanthropic responsibilities - encompass the ecological, political and environmental components of CSR. CSR has both legal/social contract theory and political governance structures to mitigate the impact of externalities on corporate performance (Turcsanyi and Sisaye, 2013).

Sustainability can provide a competitive advantage for learning and innovation to secure control of valuable and scarce resources (Sisaye and Birnberg, 2014). Organizations with sustainability programs respond better by developing new technological innovations to adapt to their changing environment. The resource-based view uses EC to examine an organization's response to environmental changes.

\section{Evolutionary economics (EC)}

EC examines organizations' "resources, competencies and trajectories" (Durand, 2001, p. 398).

It focuses on the internal pressures of environmental selection when examining forms of organizational behaviors and routines and their responses to environmental changes (Peukert, 2001). Accordingly, organizations' behavior is governed by the economic selection mechanism where firm decisions are made according to profitability rules of exogenous factors involving shifts in consumer demand and supplier input prices, which can influence investment decisions (Nelson et al., 1974, pp. 891, 893). Nelson et al. (1974) provided the foundation for EC (see also Nelson et al., 2018), where disciplines in business management and sociology extend the approach to study the economics and social evolution aspects of corporate governance and structures (Hodgson and Lamberg, 2018).

Crifo and Forget (2015) classified the EC of CSR as a private response to market imperfections to satisfy social preferences arising from regulation, competition or contracts. They classified market imperfections driving CSR decisions into three categories: public goods of altruism; imperfect competition and incomplete contracts. Using the Carroll (2015) definition of CSR, businesses engage in altruism because they see CSR within the framework 
that has benefits for them as well as society. However, Crifo and Forget (2015) noted an economic gap between CSR and financial performance, as well as between CSR and social and environmental performance. They asserted that there is a twofold discrepancy between CSR drivers and CSR impacts and a gap between CSR financial and social consequences affecting the trade-off between ecological and other transaction costs.

The underlying premise in ecological economics is that when the environment changes, organizations rely on research and development or the trial-and-error process of organizational learning to solve their problems. Nelson et al. (1976) indicated that the process of change is governed by "an economic selection mechanism" that organizations employ selectively, including expansion when there is profitability and contraction when there is loss (pp. 91-92). In accounting the EC approach to resource-based view of the firm is the predominant view that has influenced financial accounting theory of profitability and economic return in tangible assets and capital investment decisions. Organizational domains are thus affected by economic resources and transaction costs where geographical location and spatial characteristics limit resource domain and availability.

\section{TCE, organizational development and sustainability}

The interrelationship of ecology and environmental sustainability has its basis in Williamson (1987) transactional cost and economics paradigm. Williamson (1987) introduced the TCE analysis to the study of organizations and change. TCE assumes that there are differences among organizations "because transactions differ so greatly, and efficiency is realized only if governance structures are tailored to the specific needs of each type of transaction" (p. 568). Transactions then become the unit of analysis. He noted that managing transaction costs is necessary because they constitute "the crucial importance of organizations for economizing on such costs" (p. 568). Williamson (2005) further described businesses as having complex contract and economic organization having both technological (production function) and organizational (governance) structures. He elaborated that firms and markets have capacities to organize transactions, which differ in their complexity, to economize on transaction costs. Van de Ven (1986) referred to transactions as "micro-elements of macro-organizational elements" (p. 598).

Sustainability and CSR can be viewed as bundle of transaction costs that require governance structures to manage them. These transactions involve the proliferation of functions and roles for managing CSR. Stakeholder management necessitates organizational systems having interdependent functions for managing transaction costs and CSR.

The TCE assumes that human and societal decisions have ethical dimensions and economic consequences that impact sustainability business and that these transactions transcend economic and ecological objectives. Transaction analysis assumes trade-offs will be made between economic profitability goals and ecologically formulated sustainability accounting principles. Accordingly, sustainability is an organizational resource that has both normative - profitability and corporate governance - as well as altruism: social and environmental dimensions (CSR) of institutional legitimacy and accountability.

\section{The integration of the selection mechanism, transactional cost approach to CSR and legitimacy for sustainability}

Organizational ecology has advanced the literature on sustainability management and accounting by linking population ecology of selection mechanism, environmental resources management, EC, transaction costs and sustainability of production, service and managerial systems. Ecologically, sustainability management is a selection approach that is a continuous, ongoing process, not a onetime improvement or action program advocating specific government, legislative, policy or program. In this context, sustainable development 
JBSED

2,2

104

and sound environmental management constitute the primary components for establishing organizational selection and natural resource ecological relationships. This is because both population and industrial growth are potential threats for environmental destruction (Penn, 2003). At the same time, people within and outside the organization are also concerned for environmental conservation and attempt to limit industrial growth by focusing on natural resource conservation.

The Brundtland Report (1987) has presented a transactional cost analysis approach that relates sustainability, natural resource management, agricultural production, food supply, environmental protection and global climatic changes with ecological variations/modifications brought by drought, floods and other natural disasters. Resource transactions cover production and consumption decisions that occur when humans interact with the environment to exploit and conserve natural resources.

Organizations selectively adopt incremental changes in their business operations to minimize transaction costs that may impact the profitability of their core domains. Overtime, when these changes are institutionalized, they provide legitimacy for sustainability accounting and reporting systems. Organizations justify legitimacy to generate slow paced change in routines and procedures that involve prescription of accounting rules to support ongoing activities and functions to guide their daily operating activities. Overtime, when accounting rules become close to the core of the organizations' administrative activities, they tend to become functionally mechanistic and shielded from external environmental changes.

While businesses' environment necessitated changes in sustainability, the impact of these changes on accounting regulations and CSR has been limited. These rule changes have become bureaucratic since they perpetuated and co-opted existing administrative procedures. However, incremental changes in accounting reporting systems, including sustainability reporting, have been routine and prescriptive, conforming to the functional assumptions of system maintenance. When accounting systems become functional, they face inertia, thereby becoming less flexible and resistant to change. However, inertia in accounting is a relatively short-term phenomenon that is amenable to environmental changes. CSR is an inertia low-paced change that is routine. It is a functional sustainable accounting reporting format for environmental and social disclosures as part of external reporting systems.

\section{Section two: implications of organizational ecology to CSR}

CSR has its theoretical foundations in organizational/population ecology of the selection approach of the external view of the firm and the stakeholders' theory of business. The stakeholders' approach assumes that CSR objectives are in line with corporate interest groups who seek information on environmental protection, consumer safety and social philanthropic activities. CSR enables businesses to contribute to the betterment of society. CSR enhances corporate image within the community and society.

\section{The selection approach to the stakeholder view of business}

The stakeholder theory assumes that business organizations have several stakeholder groups besides stockholders with overlapping objectives and interests. They "include employee(s), customers, the local community, government agencies, public interest groups, trade associations and competitors." Other stakeholders include suppliers, employees, financiers (stockholders, bondholders, banks) and societies. These groups are "legitimate partners in a business" that the business organizations must account for them (Banerjee, 2002, p. 179). The selection approach implies that while businesses do consider all external stakeholders, they choose selectively those stakeholders who have direct and immediate interests on the organization activities. Selection in this context has an EC domain integrated with the TCE. 
Ketokivi and Mahoney (2016) noted that TCE "is a stakeholder theory of governance that emphasizes the long-term cooperation of the key stakeholders (whomever they happen to be in the specific setting) in a way that enables economic transactions with minimal waste" (p. 133). TCE views firms as consisting of heterogeneous stakeholder groups that have a set of defined relationships among them. TCE specifies three principles for the foundations of stakeholder theory: stakeholder cooperation, engagement and responsibility (p. 132). That means each group is a stakeholder that has a stake in the activities that create value for the business. The interactions and activities of these groups generate transaction costs and trade-offs of the organization's economic activities (Ketokivi and Mahoney, 2017). These transaction costs and trade-offs are selectively incurred by organizations to manage their operating performances.

The stakeholder approach has the premise that the composition, the diversity and independence of board members increase the disclosure of sustainability information (Fuente et al., 2017). This assumes that if the corporation has the functional selective existence of an independent committee or task force, specifically assigned for CSR, it can impact the dissemination of sustainability information. CSR strategy, when embedded in the selection mechanism, focuses on environmental protection and natural resource preservation, social responsibility, and the ethical performance strategies that have sustained community economic growth. Sustainability concerns such as greening influence new product development, investments in research development, location of new industries and managing pollution control.

Kotonen (2009) interpreted the stakeholders' point of view as implementing "regulated CSR reporting" both nationally and internationally to increase the importance of CSR in business strategies. (p. 198). Business organizations that have a proactive view of sustainability use CSR to selectively document their responsiveness to stakeholders' interests through compliance of government regulatory guidelines, working with shareholders, customers, shareholders, civic groups, organized interests and the community. CSR addresses environmental concerns and aligns businesses' strategies with their competitors and industry requirements.

Buysse and Verbeke (2003) associated proactive corporate strategy with environmental leadership. In their study of water pollution and solid waste production management in Belgium, they reported that firms with environmental leadership strategy were responsive to the business stakeholders and international competitors if they were multinational corporations (MNCs) that operated globally. A company's size and affiliation to MNCs as a subsidiary have resulted in affiliates being more responsive to environmental strategies. These MNC's affiliates attached selective importance to international competition and showed responsiveness to overall environmental strategies. These MNC's affiliates are bigger in size, have resources and value the importance of environmental leadership to international competition than local concerns (pp. 466-467). Since most of these MNCs follow GRI guidelines in their CSR, their strategy for meeting international environmental standards have exceeded those of local regulatory requirements.

Kotonen (2009) reported that Finnish companies have utilized the stakeholders' approach in their CSR disclosure. CSR aligns with GRI guidelines to meet various stakeholders' interests, including the international community. Moreover, CSR was integrated with annual reports to present the companies' social, environmental and economic performances consistent with the Brundtland (1987) Report guidelines. Although environmental management enhances a corporate/business image, as the organization establishes better public awareness and working relationships with the community, these policies do require significant transaction costs and trade-offs between profitability and environmental stewardships. The returns from these investments are less likely to be realized in the short term with negative accounting earnings and returns (Turcsanyi and Sisaye, 2013). 
JBSED

2,2

106
The functionality of CSR in improving organizational performance

The outcome of the stakeholder approach in sustainability reporting is CSR. CSR is an example of a functional sustainable accounting reporting format rooted in organizationalwide system maintenance strategy. CSR objectives are functional because they align with corporate interest groups. They serve as a public relations outlet for fulfilling the external reporting objectives of the organization through disclosure of environmental protection, consumer safety and social philanthropic activities. CSR has enhanced the functionality of sustainability values and principles in shaping organizations strategic plans, missions and policy guidelines.

Lopez et al. (2007) summarized CSR strategies as comprehensive and integrative policies ranging from "management quality environmental arrangement, brand reputation, customer loyalty, corporate ethics and talent retention," as well as practices that are related to better corporate management, environmental protection, ethics and full disclosure of sustainability development practices. The accounting implications are cost savings, improved internal controls and quality decision-making. These policies are expected to create long-term value and performance for the organization (p. 286). Accordingly, CSR has become a risk reduction environmental management strategy.

(1) CSR and environmental risk reduction strategy

Frynas and Stephens (2015) suggest that the political strategy of CSR is to manage risk. CSR has an organizational ecological governance structure, where the corporate board comprises members from nongovernmental organizations (NGOs) (Sisaye, 2021) or as, Lake (2021) referred to them, private governance organizations (PGOs). Ecologically, CSR is an SF organizational management strategy to manage business sustainability performance. The SF approach infers that CSR has a materiality dimension to enhance the functionality of an organization, which has the characteristics of both an enduring and living entity (i.e. growing concern). This approach is consistent with Duxbury and Jeannotte's (2012) view of sustainability, which focuses on the physical ecology, emphasized by the interconnections of the organization with the environment, society and the economy. Sustainability manages organizational risk by promoting functional link and interdependence functions among the various entities of the organization.

CSR discloses information that has the objective of mitigating environmental risks, as it covers all business activities including labor practices, consumer protection, community involvement, human rights, corporate governance as well as social welfare (Reverte, 2012, p. 255). When reported, CSR disclosures supplement external financial reporting by incorporating social and environmental data to concerned constituencies. CSR may serve as a risk reduction strategy of environmental matters, as it increases firms' abilities to respond to the media and regulators' compliance policies (Morhardt, 2010). It gives functional credence to corporate social and environmental activities leading to legitimization of institutionalized norms and behavior.

(2) CSR and competitive advantage

There is a consensus among researchers that CSR is more likely to provide firms with long-term competitive advantage compared to others who exhibit lower CSR concerns/orientations (Lee and Pati, 2012). Organizations pursue CSR strategies when environmental and social concerns are associated with a competitive advantage that improves financial performance.

Clark and Allen (2012) examined the relationship between sustainability leadership (CSR) and accounting performance. They used the Dow Jones Sustainability Index (DJSI) listings and memberships as a proxy for sustainably led companies. They reported that sustainable leadership improved the financial valuation and quality of earnings. Although it is a 
qualitative attribute, the market perception was positive and "that achieving sustainability leadership is a strategy that is consistent with maximizing shareholder value" (p. 115). Overall, their study indicated that even though sustainability investments are considered "operating expenses allocated to "nonmarket" activities" that may affect the accounting bottom line factors of net income and other profitability indicators, because of these investments," shareholder wealth may still increase if investors assign a higher valuation multiple to lower earnings" (p. 116). That is, investments in discretionary areas that may not increase bottom line performance measures may contribute to "increases in shareholder value," which is associated with sustainability leadership. They valued membership in DJSI as contributing to higher valuations of financial assets and earnings quality when compared to those non-DJSI member firms.

\section{(3) CSR and organizational performance}

While CSR reports are effective in stakeholder's engagement, the association between CSR and business financial performance is mixed. Turcsanyi and Sisaye (2013) reported that CSR has a negative economic performance in the short term although long-term gains from economic performance are not that significant.

Reverte (2012) questioned whether improved CSR increases firm value through reduction of the cost of equity capital. While improved CSR provides more disclosure on a company's sustainability performance, by reducing information asymmetry and increasing transparency, there is no association with increased firm value. Reverte (2012) study indicated that if an increase in contents of CSR is evidenced in an increase in CSR rating, it has the potential to decrease the cost of equity capital. That is, "the cost of equity capital is an important channel through which the market prices CSR disclosure" (p. 263). However, the results showed "a negative relationship between CSR disclosure quality and cost of equity capital is more pronounced for those firms operating in environmentally sensitive industries" (p. 266). The CSR disclosures indicated quality of management and responsible reporting that are value neutral. They did not contribute to market valuation of the firm by reducing the cost of equity capital.

Chen et al. (2015) examined the relationships between GRI/CSR disclosure and financial performance in 75 manufacturing industries. They noted that while societal concerns and quality of products are associated with financial performance, CSR practices do not necessarily contribute to accounting indicators of performance.

Ioannis and Serfeim (2015) found that although financial analysts are receptive to CSR, the ratings are mixed although the trend is towards favorable assessment of CSR ratings. That is, the association between CSR ratings and financial performance are mixed. However, from a strategic management perspective, corporations with CSR have competitive advantage over others who do not have sustainable practices (Keong et al., 2017). These shortcomings in CSR reports can be attributed because they are not part of the financial accounting disclosure reports. They are generated as supplementary reports for a specific function to selectively meet social and environmental reporting.

\section{(4) The diversity of CSR reports}

CSR reports have drawbacks because of the lack of uniformity and standardization in reporting formants. Morhardt (2010) found that organizational size and industrial sectors do account for differences in CSR containing sustainable social and environmental performances. While medium and large size firms respond to social issues in response to their internal and external pressures, in smaller companies, information cost becomes a factor to not fully adopt CSR. Moreover, industrial sector characteristics do account for CSR differences. In industries that have "established environmental sensitivity and substantial 
JBSED

2,2

108 direct impact in sectors such as manufacturing, resources, utilities, chemicals, pharmaceuticals, motor vehicles and part" as well as in banks, retailing, food, etc. With direct contact with customers, there is a CSR orientation to inform the public (p. 408). These sectors show awareness and responsibility by issuing CSR disclosures that are varied and lack uniformity and comparability among businesses within the same industry.

The literature suggests that there are variations in the CSR disclosure formats among countries and industries. In developed economies, CSR reporting is varied according to the political orientations of the country, for example, among the Nordic, Western Europe and other industrially developed countries. Nordic countries have liberal political governments and pluralistic democratic institutions that have encouraged detailed and comprehensive CSR disclosures. Kotonen (2009) described the CSR of Finnish companies as comprehensive, as it followed GRI guidelines by reporting environmental issues, employee welfare, ethical behavior as well as corporate involvement in community-based projects, natural disaster help, support for education, donation to charities and youth groups, among others. The reports include both qualitative and quantitative information highlighting "transparency, openness, materiality, and in some cases fairness" (p. 190). It is evident that the Nordic countries with their social democratic political systems are more likely to disclose sustainability information when compared to those countries with pro-business conservative environmental policies.

Moreover, the extent of disclosure of CSR information also vary according to industries, size of the company and whether the corporations are privately or publicly owned and operated nationally or internationally. Reverte (2012) reviewed the contents of CSR for several industrial organizations' and reported that industries from oil, mining, chemical and pharmaceutical companies disclose information on environmental, health and safety issues related to their operations and the industry at large. Turcsanyi and Sisaye's (2013) study of the CSR disclosure in the pharmaceutical industry found that Johnson \& Johnson disclosed sustainability information on medical safety and health impacts of medication pills on consumers and safety measures the company instituted to protect consumers' welfare. These studies indicate that the size of the company, public ownership and international involvement are associated with increased information in CSR.

These studies suggest that the current trend among industrially developed countries' business organizations is for increased CSR disclosures. CSR reports contain transaction costs related to accounting capital and operating budgeting issues, as well as financial future risk, which are strategic implications of corporate sustainability activities. These costs are incurred in meeting regulatory requirements and in future contingent liabilities associated with operating assets. They are incremental supplementary voluntary reports provided in addition to the mandatory annual report. This reporting trend shows that finance and accounting can provide a multi-functional and multi-purpose approach to transaction costs and sustainability accounting by integrating environmental issues, management of risk as well as measuring operating performance, and strategic plans.

(5) CSR and sustainability performance data disclosures

Organizational ecological factors ranging from institutional, legal, governmental, competitive and international factors have shaped organizational structures and systems to adopt CSR that imitate and conform to social and environmental accounting standards. By mimicking and accepting normative industry standards, conformance and compliance has provided legitimacy and stability for those organizations who have adopted GRI guidelines in the organizations administrative procedures to meet the demands of their diverse constituents. They use GRI in disclosing sustainability indicators of performance to their stakeholders (Christofi et al., 2012; GRI, 2021a, b). They have achieved continuous operating profitability improvements over time. 
CSR has enabled sustainably oriented organizations with dual functional roles that are purposive for continued business performance. First, from a public relations viewpoint, CSR reports are effective in increasing stakeholder proactivity and interest towards corporations (Lim and Greenwood, 2017). That is, stakeholders are positively engaged in the corporation's business performance and social responsibility goals. Second, although there are variations in the level of environmental performance disclosures by industrial sectors, corporations who have adopted GRI disclosed a wide range of information in their CSR reports. The range of information reported in CSR and the adoption of GRI guidelines in sustainability reporting have established a generally accepted reporting guidelines for a comprehensive sustainability disclosure.

The multiple goals of sustainability require managers to pursue innovative strategies of accounting rules change. According to Borins (2014), innovation has three components: a program doing something new or differently, agents responsible for implementing the program and the organizational context within which the program is implemented (p. 14). Adoption of these innovations depends on the perceived levels of gains or losses associated with the innovation (Ax and Greve, 2017). Accounting innovations of sustainability through CSR and GRI follow these guidelines.

\section{Section three: the synergy between CSR and GRI}

CSR provides the underlying framework for the GRI strategy and reporting (Wilburn and Wilburn, 2013). While GRI has also evolved into an international and global framework, its frame of reference is based on CSR. Haque and Jones (2020) indicated that European firms who have adopted GRI have also complied with GRI standards of reporting. They have developed a comprehensive CSR strategy for biodiversity disclosure of business performance. The GRI guideline has become the basis for a comprehensive CSR report.

\section{GRI and the adoption of CSR}

The GRI's global framework of reference has facilitated the adoption and diffusion of CSR. The CSR report has become an umbrella for GRI standards and the sustainable development programs advocated by the United Nations Sustainable Development Guidelines (SDG) (ElAlfy et al., 2020.) As more organizations use GRI, sustainable data information is disclosed in CSR reports. The media has played a role in publicizing good corporate practices and, at the same time, as a watchdog by exposing corporate unsustainable practices. The media has thus helped to speed up the adoption of GRI as GRI received media coverage, publicity and exposure.

Stakeholders do exercise power and legitimacy to influence corporations on the details of sustainability information disclosed in CSR (Perez et al., 2017). Fuente et al. (2017) reported that the disclosure of sustainability information was associated with the composition and the diversity of board members. Independence of corporate boards and the functional existence of an independent committee or task force are specifically assigned for CSR.

\section{The functionality of CSR information in GRI standards}

The outcome of the stakeholder transaction cost approach in sustainability reporting is the link between GRI and CSR. The GRI reporting guidelines have contributed to the development of integrated reporting (IR) for the disclosure of sustainability information in CSR for participating corporations (de Villers et al., 2014, 2017). CSR is an outcome of the functionality systems maintenance assumptions of sustainability accounting reporting systems. CSR has become a public relations outlet for fulfilling the internal and external 
JBSED

2,2

110

reporting objectives of the organization's strategic plans, missions and policy guidelines of sustainability values and principles.

\section{Functionality of accounting rules in CSR: materiality and sustainability}

The functional assumptions in accounting have been embedded in materiality principles of accounting theory. These principles are incorporated in CSR and GRI reporting guidelines. In other words, for a rule to be functional, it must be based on the principles of materiality. The materiality assumption has been extended to provide theoretical foundations to sustainability accounting. For example, Ivan (2009) pointed out two inter-related factors: materiality (from accounting theory) and sustainable development, as contributing to the general guidelines for integrated sustainability accounting and reporting systems. The first factor is related to the "materiality of sustainability and its relationship to firm performance." This is derived from GRI, which provides reporting guidelines for sustainability performance. The second factor is related to the extent to which business organizations "respond to issues of sustainable development" as defined by the Brundtland (1987) report (p. 107), also reflected in GRI.

The dual concepts of materiality and sustainable development constitute the functional assumptions in sustainability accounting. The first concept materiality is based on the accounting principle of the going concern. Gary et al. (2011) used the accounting materiality argument to advance the importance of sustainability accounting. They suggested that if a business organization is not sustainable, "it implies a lack of going concerns" (p. 101). Torelli et al. (2020) espouse the importance of GRI in promoting the materiality principle by incorporating standards that are accepted by members in the inclusion of sustainable information that reports stakeholder engagement, business practices in society and employee involvement and satisfaction in the business performance of organizations. The engagement of stakeholders in a corporation's environmental performance is dependent on the materiality of the information contained in sustainability reports. The inference from these studies is that the concept of materiality and sustainability are interrelated strategic components that business organizations need to implement to operate in the long-term as continuously functionally living entities.

The second factor, sustainable development, mentioned by Ivan (2009) has been advanced by the Brundtland (1987) report, which made sustainability a global issue. The report highlighted the availability of resources for current and future generations depended on resource conservation and environmental protection management practices. International development organizations, government regulatory, societal and policymaker's awareness of climatic change, and business policies to meet regulatory requirements and legislation to avoid transactional costs and unanticipated risks and consequences have led to the incorporation of sustainability indicators in financial accounting reporting systems.

These studies corroborate that sustainability and materiality are integrated and comprise the three elements of business performance: social, environmental and financial. Sustainability becomes material when issues of social and environmental indicators are included in financial reports, such as GRI. Materiality in accounting has financial performance indicators when it is related to sustainability indicators. Materiality is linked to the functional assumptions of business as living entities. Sustainability in business is based on the going concern principle in accounting because a business entity that is sustainable is adaptive and meets the concept of going concern. Otherwise as the population ecology selection mechanism suggests, unsustainable business organizations will die and thus are not living entities. Both materiality and sustainability constitute the underlying ecological adaptation and selection principles of CSR. 
Section four: conclusion - CSR, sustainability accounting and future research directions

This research has provided an integrated approach of organizational and population ecology and selection mechanisms within the context of the resource-based view of the firm, EC and the TCE. The stakeholder theory has been used within the context of TCE to examine the interrelationships between sustainability development and CSR. The research has highlighted that CSR has been embedded in GRI as more business organizations selectively use CSR. They have adopted a more inclusive approach towards the sustainability reporting of an organization's financial, environmental and social performances.

Theoretically, there are two interrelated issues associated with CSR and sustainability reporting. First, there are concerns as to whether sustainability information can be captured with prescribed, defined and well-specified accounting rules for reporting. The argument is that sustainability is ecologically broader and encompasses organizations' strategic, legal and personnel issues, sales, production, supply chain management, marketing and finance functional areas (Gary et al., 2011). In other words, there are questions as to whether sustainability can be effectively covered in CSR reports because sustainability includes the whole business enterprise system.

The second issue is related to GRI and IR, and whether the topics covered in sustainability can remain broad or narrowed to environmental and social information (de Villiers, 2017). An integrated accounting guideline that includes sustainability information has not yet been formalized as part of financial reporting. Rather it has resulted in the proliferation of CSR that are varied in the scope of information. They are not uniformly presented to compare business performances by industries or markets for investors and interested stakeholders who seek comparable information. CSR is not mandated as a formal accounting report.

CSR is voluntary and has its basis on the assumption that business responds better to society when there are no mandatory rules for external reporting. It is a philanthropic principle that business contributes to the betterment of society when it is not regulated. Business is self-interested when enhancing its corporate image within the community and society. Voluntarism has drawbacks in mandating sustainability reporting. Nevertheless, the big four accounting firms and NGOs have argued for the inclusion of CSR and GRI as part of the IR of business organizations.

Ecologically, sustainability accounting and reporting is still in the evolutionary development stage and requires time to significantly change from the current voluntary to mandatory reporting formats. While there is a progress and evolutionary change process for the development of an integrated sustainability reporting guidelines, there is a selection mechanism as to which guidelines can be adopted. When corporations adopt innovations in accounting reporting systems, they selectively choose those innovations that require minimal transaction costs. Adoption of selective innovations generate public acceptance from stakeholders, favorable media coverage. It can reduce oversight and externality transaction costs associated with compliance from government regulatory organizations.

The literature on sustainability accounting innovations has focused on the functionality principles of sustainability performances that call for incremental innovations in accounting systems. Schaltegger et al. (2017) documented that accounting innovations require managers to develop new and/or improved accounting techniques to record and report corporate sustainability management and development practices consonant with economic performance and societal well-being. They suggested that sustainability accounting innovations require that the focus be placed more on key sustainability issues to develop new accounting methods and processes to support industry and market transformations. Baldassarre et al. (2017) argued that beyond accounting techniques, corporations can develop and integrate a sustainable business model innovation that is based on user-driven
The ecology of corporate social reporting 
JBSED

2,2

112

innovation that involves customers and other stakeholders more systematically. The integrated approach can add values and new perspectives on sustainability, which adds sustainable value for business and society (de Villiers et al., 2014, 2017). Borins (2014) reaffirmed that managers can be more responsive to citizen needs by hiring environmental management leaders and having a clear strategic vision of corporate social responsibility. These undertakings involve transaction costs and economic risks associated with accounting indicators of economic performance.

Hahn et al. (2018) extended the functionalist view denoting that sustainability performance can be objectively verifiable and inherently transparently measured and compared with standardized reports. In contrast, organizational ecologists assume that sustainability is broad in context and is nonmeasurable. The functionalist view denotes sustainability accounting as consonant with CSR and GRI, where quantifiable sustainability indicators of performance can be developed to record economic, environmental and social performances. The ecological approach questions whether an innovative accounting approach that follows a functional incremental innovation strategy would transform sustainability reporting into CSR. The functionalist argues that CSR can be expanded through GRI. Ecologically, the selective approach of sustainability reporting will not materialize within the limited incremental approach of CSR.

GRI's limitations include the fact that sustainability reporting is incremental. It has narrowly focused on the organization rather than the ecosystem at large. It has not included the sociopolitical system that regulates business and environmental systems and management of resources. Nevertheless, the CSR/GRI approach to sustainability accounting has incrementally contributed to the development of an inclusive reporting system that encompasses both the economic/financial, environmental and social performances disclosures of business organizations. The report can internally improve the financial performance of the organization. Externally, it becomes a public relations mechanism for reporting to stakeholders the economic, social and environmental performances of business organizations. However, a comprehensive reporting system is less likely to materialize unless sustainability reporting is mandated by accounting standard setting bodies and government regulatory agencies.

GRI's functionality allows it to develop new processes and establish standardized guidelines for reporting sustainability data and performance (Sisaye, 2021). It also increases comparability and efficiency of information management and reporting on a detailed level (Schaltegger et al., 2017). Over the years, GRI has evolved into IR by incorporating CSR and sustainable performance data. IR has incorporated a general guideline for a nonfinancial reporting format indicating what information should be included, and how the disclosed data should be organized in the annual corporate report (de Villiers et al., 2014, 2017; Idowu et al., 2016; Sisaye, 2021). In other words, sustainability reporting is a selection mechanism giving birth to IR by reducing the transaction costs and mortality rates of CSR and GRI. IR is evolving as an integrative framework for both CSR and GRI.

\section{References}

Astley, W.G. (1985), "The two ecologies: population and community perspectives on organizational evolution", Administrative Science Quarterly, Vol. 30 No. 2, pp. 224-241.

Ax, C. and Greve, J. (2017), "Adoption of management accounting innovations: organizational culture compatibility and perceived outcomes", Management Accounting Research, Vol. 34 Mar 2017, pp. 59-74.

Baker, W.E., Faulkner, R.R. and Fisher, G.A. (1998), "Hazards of the market: the continuity and dissolution of inter-organizational market relationships", American Sociological Review, Vol. 63 No. 2, pp. 147-177. 
Baldassarre, B., Calabretta, G., Bocken, N. and Jaskiewicz, J. (2017), "Bridging sustainable business model innovation and user-driven innovation: a process for sustainable value proposition design”, Journal of Cleaner Production, Vol. 147 Mar 2017, pp. 175-186.

Banerjee, S.B. (2002), "Corporate environmentalism: the construct and its measurement", Journal of Business Research, Vol. 55 No. 3, pp. 177-192.

The ecology of corporate social reporting

Bansal, P. (2005), "Evolving sustainability: a longitudinal study of corporate sustainable development", Strategic Management Journal, Vol. 26 No. 3, pp. 197-218.

Barnett, W.P. and Carroll, G.R. (1995), "Modeling internal organizational change”, Annual Review of Sociology, Vol. 21, pp. 217-236.

Barney, J.B. (2001), "Is the resources based 'view' a useful perspective for strategic management research? Yes”, Academy of Management Review, Vol. 26 No. 1, pp. 41-56.

Barron, D. (1999), "The structuring of organizational populations", American Sociological Review, Vol. 64 No. 3, pp. 421-445.

Borins, S.F. (2014), "Emergence and diversity: public sector innovation research", The Persistence of Innovation in Government, Vol. 8, pp. 11-39, Brookings Institution Press, Washington D. C..

Brundtland Report, Chair, The World Commission on Environment and Development (1987), Our Common Future. The World Commission on Environment and Development (WCED), Oxford University Press, New York, NY.

Buysse, K. and Verbeke, A. (2003), "Proactive environmental strategies: a stakeholder Management perspective", Strategic Management Journal, Vol. 24 No. 5, pp. 453-470.

Carroll, G.R. (1984), "Organizational ecology”, Annual Review of Sociology, Vol. 10, pp. 71-93.

Carroll, A.B. (1991), "The pyramid of corporate social responsibility: toward the moral management of organizational stakeholders", Business Horizons, Vol. 34 No. 4, pp. 39-48.

Carroll, A.B. (2015), "Corporate social responsibility: the centerpiece of competing and complementary frameworks", Organizational Dynamics, Vol. 44 No. 2, pp. 87-96.

Chen, L., Feldman, A. and Tang, O. (2015), "The relationship between disclosure of corporate social performance and financial performance: evidence from GRI reports in manufacturing industry", International Journal of Production Economics, Vol. 170 part B, December, pp. 445-446.

Christofi, A., Christofi, P. and Sisaye, S. (2012), "Corporate sustainability: historical development and reporting practices", Management Research Review, Vol. 35 No. 2, pp. 157-172.

Clark, T.S. and Allen, D.S. (2012), "Shareholder value from sustainability leadership: comparing valuation ratios within industry groups", International Research Journal of Finance and Economics, Vol. 89 April, pp. 108-117.

Crifo, P. and Forget, V.D. (2015), "The economics of corporate social responsibility: a firm-level perspective survey", Journal of Economic Surveys, Vol. 21 No. 1, pp. 112-130.

de Villiers, C., Venter, E.R., Hsaio, P.C.K., Rinaldi, L. and Unerman, J. (2014), "Integrated reporting: insights, gaps and an agenda for future research", Accounting, Auditing and Accountability Journal, Vol. 27 No. 7, pp. 1042-1067.

de Villiers, C., Venter, E.R. and Hsaio, P.C.K. (2017), "Integrated reporting: background, measurement issues, approaches and an agenda for future research", Accounting and Finance, Vol. 57 No. 4, pp. 937-959.

Durand, R. (2001), "Firm selection: an integrative perspective”, Organization Studies, Vol. 22 No. 3, pp. 393-417.

Duxbury, N. and Jeannotte, M. (2012), "Including culture in sustainability: an assessment of Canada's integrated community sustainability plans", International Journal of Urban Sustainable Development, Vol. 4 No. 1, pp. 1-19. 
JBSED

2,2

114

ElAlfy, A. (2020), Redefining Strategic Corporate Social Responsibility (CSR) in the Sustainable Development Goals (SDGs) World, Unpublished Ph.D. dissertation, University of Waterloo, Ontario, Canada (accessed 8 October).

Frynas, J.G. and Stephens, S. (2015), "Political corporate social responsibility: reviewing theories and setting new agendas", International Journal of Management Review, Vol. 17 No. 4, pp. 483-509.

Fuente, J.A., Garcia-Sanchez, I.M. and Lozano, M.B. (2017), "The role of the board of directors in the adoption of GRI guidelines for the disclosure of CSR information", Journal of Cleaner Production, Vol. 141 No. 10, pp. 737-750.

Gary, C.M., Fagerström, A. and Hassel, L.G. (2011), "Accounting for sustainability: what next? A research agenda", Annals of the University of Oradea, Economic Science Series, Supplement, pp. 97-111.

Global Reporting Initiative (GRI) (2021a), GRI Sustainable Performance, available at: https://www. sustainable-performance.total.com/en/reporting/reporting-standards/global-reporting-initiativegri (accessed 20 May).

Global Reporting Initiative (GRI) (2021b) , available at: https:/www.globalreporting.org/about-gri/ (accessed 21 May).

Hahn, T., Figgs, F. and Pinske, J. (2018), "A paradox perspective on corporate sustainability: descriptive, instrumental, and normative aspects", Journal of Business Ethics, Vol. 148 March, pp. 235-248.

Hannan, M.T. (1977), "The population ecology of organizations", American Journal of Sociology, Vol. 82 No. 3, pp. 929-964.

Haque, F. and Jones, M.J. (2020), “European firms' corporate biodiversity disclosures and board gender diversity from 2002 to 2016", The British Accounting Review, Vol. 52 No. 2, pp. 68-73.

Hart, S.L. (1995), “A natural resource based view of the firm”, The Academy of Management Review, Vol. 20 No. 4, pp. 986-1014.

Hodgson, G. (2013), "Understanding organizational evolution: toward a research agenda using generalized darwinism”, Organization Studies, Vol. 34 No. 7, pp. 973-992.

Hodgson, G. and Lamberg, J.-A. (2018), "The past and future of evolutionary economics: some reflections based on new bibliometric evidence", Evolutionary and Institutional Economics Review, Vol. 15 No. 1, pp. 167-187.

Idowu, S.O., Dragu, I.M., Tiron-Tudor, A. and Farcas, T. (2016), "From CSR and sustainability to integrated reporting", International Journal of Social Entrepreneurship and Innovation, Vol. 4 No. 2, pp. 134-151.

Ioannou, I. and Serafeim, G. (2015), "The impact of corporate social responsibility on investment recommendations: analysts' perceptions and shifting institutional logics", Strategic Management Journal, Vol. 36 No. 7, pp. 1053-1081.

Ivan, O.R. (2009), "Sustainability in accounting-basis: a conceptual framework", Annales Universitatis Apulensis Series Oeconomica, Vol. 11 No. 1, pp. 106-116.

Keong, L.B., Ramakrishman, S. and Hishan, S.S. (2017), "The review of corporate social responsibility (CSR) literature in the new millennium", Advanced Science Letters, Vol. 23 No. 9, pp. 9271-9274.

Ketokivi, M. and Mahoney, J.T. (2016), "Transaction cost economics as a constructive stakeholder theory", Academy of Management Learning and Education, Vol. 15 No. 1, pp. 123-138.

Ketokivi, M. and Mahoney, J.T. (2017), "Transaction cost economics as a theory of the firm, management, and governance", Oxford Research Encyclopedia of Business, Vol. 2017 (accessed 20 May 2021).

Kotonen, U. (2009), "Formal corporate social responsibility reporting in Finnish listed companies", Journal of Applied Accounting Research, Vol. 10 No. 3, pp. 176-207.

Lake, D.A. (2021), "The organizational ecology of global governance", European Journal of International Relations, Vol. 27 No. 2, pp. 345-368. 
Lee, J. and Pati, N. (2012), "New insights on the operational links between corporate sustainability and firm performance in service industries", International Journal of Business Insights and Transformation, Vol. 4 No. 3, pp. 80-93.

Levinthal, D.A. and Marino, A. (2015), "Three facets of organizational adaptation: selection, variety, and plasticity", Organization Science, Vol. 26 No. 3, pp. 743-755.

The ecology of corporate social reporting

Lim, J.S. and Greenwood, C.A. (2017), "Communicating corporate social responsibility (CSR): stakeholder responsiveness and engagement strategy to achieve CSR goals", Public Relations Review, Vol. 43 No. 4, pp. 768-776.

Lopez, M.V., Garcia, A. and Rodriguez, L. (2007), "Sustainable development and corporate performance: a study based on the Dow Jones sustainability index", Journal of Business Ethics, Vol. 75 No. 3, pp. 285-300.

Morhardt, J.E. (2010), "Corporate social responsibility and sustainability reporting on the internet", Business Strategy and the Environment, Vol. 19 No. 7, pp. 436-452.

Munck, L. and Borim-de-Souza, R. (2012), "Sustainability and competencies in organizational contexts: a proposal of a model of interaction", International Journal of Environment and Sustainable Development, Vol. 11 No. 4, pp. 394-411.

Nelson, R.R., Dosi, G., Helfat, C.E. and Winter, S.G. (1974), "Neoclassical vs. evolutionary theories of economic growth: critique and prospects", The Economic Journal, Vol. 84 No. 336, pp. 886-905.

Nelson, R.R., Dosi, G., Helfat, C.E., Winter, S.G. and Schuette, H.L. (1976), "Technical change in an evolutionary model", Quarterly Journal of Economics, Vol. 90 No. 1, pp. 90-118.

Nelson, R.R., Dosi, G., Helfat, C.E. and Winter, S.G. (2018), Modern Evolutionary Economics: An Overview, Cambridge University Press, London.

Penn, D.J. (2003), "The evolutionary roots of our environmental problems: toward a Darwinian Ecology", The Quarterly Review of Biology, Vol. 78 No. 3, pp. 275-301.

Perez, A., Lopez, C. and Garcia-Delos Salmones, M.D.M. (2017), "An empirical exploration of the link between reporting to stakeholders and corporate social responsibility reputation in the Spanish context", Accounting, Auditing and Accountability Journal, Vol. 30 No. 3, pp. 668-698.

Peukert, H. (2001), "On the origins of modern evolutionary economics: the Veblen legend after 100 years", Journal of Economic Issues, Vol. 35 No. 3, pp. 543-555.

Porter, M.E. (1985), Competitive Advantage, Macmillan Publishing, New York, NY.

Reverte, C. (2012), "The impact of better corporate social responsibility disclosure on the cost of equity capital", Corporate Social Responsibility and Environmental Management, Vol. 19 No. 5, pp. 253-272.

Rudel, T.K., Roberts, J.T. and Carmin, J.A. (2011), "Political economy of the environment", Annual Review of Sociology, Vol. 37, pp. 221-238.

Rumelt, R.P. (1974), Strategy, Structure and Economic Performance, Harvard University Press, Boston.

Salimath, M.S. and Jones, R. (2011), "Population ecology theory: implications for sustainability", Management Decision, Vol. 49 No. 6, pp. 874-910.

Sarta, A., Durand, R. and Vergne, J.R. (2021), “Organizational adaptation”, Journal of Management, Vol. 47 No. 1, pp. 43-75.

Schaltegger, S., Etxeberria, I.A. and Ortas, E. (2017), "Innovating corporate accounting and reporting for sustainability-attributes and challenges", Sustainable Development, Vol. 25 No. 2, pp. 113-122.

Sisaye, S. (2021), "The influence of non-governmental organizations (NGOs) on the development of voluntary sustainability accounting reporting rules", Journal of Business and Socio-Economic Development, EarlyCite, Vol. 1 No. 1, pp. 5-23.

Sisaye, S. and Birnberg, J.G. (2014), "Sociological approaches of organizational learning: applications to process innovations of management accounting systems", Advances in Management Accounting, Vol. 23, pp. 1-43. 
JBSED

2,2

116

Stieglitz, N., Knudsen, T. and Becker, M.C. (2016), “Adaptation and inertia in dynamic environments”, Strategic Management Journal, Vol. 37 No. 9, pp. 1854-1864.

Torelli, R., Balluchi, F. and Furlotti, K. (2020), "The materiality assessment and stakeholders engagement: a content analysis of sustainability reports", Corporate Social Responsibility and Environmental Management, Vol. 27 No. 2, pp. 470-484.

Turcsanyi, J. and Sisaye, S. (2013), "Corporate social responsibility and its link to financial performance: application to Johnson and Johnson, a pharmaceutical company", World Journal of Science, Technology, and Sustainable Development, Vol. 10 No. 1, pp. 4-18.

Van de Ven, A.H. (1986), "Central problems in the management of innovation", Management Science, Vol. 32 No. 5, pp. 590-607.

Wilburn, K. and Wilburn, R. (2013), "Using global reporting initiative indicators for CSR programs", Journal of Global Responsibility, Vol. 4 No. 1, pp. 62-75.

Williamson, O.E. (1987), "The economics of organization: the transaction cost approach", American Journal of Sociology, Vol. 87 No. 3, pp. 548-577.

Williamson, O.E. (2005), "Why law, economics and organization", Annual Review of Law and Social Science, Vol. 1, pp. 369-396.

Yi, S., Knudsen, T. and Becker, M.C. (2016), "Inertia in routines: a hidden source of organizational variation”, Organization Science, Vol. 27 No. 3, pp. 782-800.

\section{About the author}

Seleshi Sisaye, Ph.D., Ph.D. is a tenured professor of accounting at Duquesne University, Palumbo Donahue School of Business. Dr. Sisaye has earned two Ph.Ds. in accounting from the University of Pittsburgh and development sociology from Cornell University. His research interests are in sustainability accounting and reporting, process innovations, management control systems, development sociology and ecological anthropology. He has published several books and numerous peer reviewed journals in accounting, management and sociology. He has presented papers at national and international conferences and published in their proceedings. Seleshi Sisaye can be contacted at: sisaye@duq.edu

For instructions on how to order reprints of this article, please visit our website:

www.emeraldgrouppublishing.com/licensing/reprints.htm

Or contact us for further details: permissions@emeraldinsight.com 